\title{
REPRESENTAÇÃO POLÍTICA, IDENTIDADE E MINORIAS 1
}

Iris Marion Young

Poucos defensores de um modelo de democracia deliberativo ou comunicativo afirmariam que ele se aplica primordialmente a situações em que as pessoas estão mutuamente presentes num mesmo espaço e por uma determinada ocasião para se defrontar e falar diretamente. No entanto, tanto na teoria quanto na prática há uma tendência a associar processos democráticos comunicativos a interações face-a-face. Quer assumam que a circunstância da discussão democrática tenha lugar numa sessão parlamentar ou num encontro de um grupo de cidadãos, esses defensores geralmente acabam por representar o processo de comunicação democrática como centrado em algum espaço onde os participantes estão mutuamente presentes.

Uma democracia forte certamente requer diversas ocasiões em que autoridades públicas e cidadãos se encon-

1. Do original (Capítulo 4) Inclusion and democracy, 2000. Somos gratos à autora pela acolhida favorável à iniciativa de traduzir e publicar este texto e à Oxford University Press pela facilidade de aquisição de direitos para a presente publicação em Lua Nova. Tradução de Alexandre Morales. 
trem para discutir determinadas experiências e questões. No entanto, teorizar a democracia como um processo de comunicação que visa chegar a decisões não condiz suficientemente com a necessidade de conceitualizar a democracia descentralizada das grandes sociedades de massa. Numa sociedade complexa e com muitos milhões de pessoas a comunicação democrática consiste em discussões e decisões fluidas, sobrepostas e divergentes, dispersas tanto no espaço como no tempo. O que são relações comunicativas inclusivas em tais sociedades fluidas, descentralizadas, de massa?

No contexto dessas sociedades são muito freqüentes as queixas que apontam o caráter excludente das normas de representação. As pessoas muitas vezes reclamam que os grupos sociais dos quais fazem parte ou com os quais têm afinidade não são devidamente representados nos organismos influentes de discussões e tomadas de decisão, tais 140 como legislaturas, comissões e conselhos, assim como nas respectivas coberturas dos meios de comunicação. Essas demandas evidenciam que numa sociedade ampla e com muitas questões complexas os representantes formais e informais canalizam a influência que as pessoas podem exercer.

Por essas razões, muitas propostas recentes de maior inclusão política nos processos democráticos defendem medidas que propiciem maior representação dos grupos sub-representados, especialmente quando esses grupos são minorias ou estão sujeitos a desigualdades estruturais. Ativistas dos movimentos de mulheres de muitos cantos do mundo, por exemplo, apontam que legislaturas ocupadas majoritariamente por homens não podem representar devidamente as mulheres. Em resposta a isso, alguns governos têm decretado medidas voltadas a proporcionar maior presença feminina nos órgãos legislativos, geralmente determinando que os partidos incluam uma certa proporção de 
mulheres nas suas listas de candidatos ${ }^{2}$. Nos países que não contam com tais dispositivos é crescente a mobilização das mulheres pela adoção de medidas nesse sentido, ao passo que diversos partidos têm reconhecido que suas listas não são devidamente representativas sem uma certa proporção de candidaturas femininas, ainda que a lei não o exija.

Nos Estados Unidos estão em curso discussões similares acerca da representação específica de minorias raciais ou étnicas. Debatem-se propostas de distritos eleitorais ou processos de votação ajustados para aumentar a probabilidade de eleição de candidatos afro-americanos ou latino-americanos. Tanto a idéia quanto a prática de promover a representação específica de minorias são controversas, mas a questão já está definitivamente incorporada à agenda pública norte-americana. Muitos outros países possuem ou discutem esquemas de representação de grupos sociais específicos, na forma de conselhos corporativos, cadeiras parlamentares reservadas, regras para listas partidárias, comissões etc.

No entanto, as políticas, as propostas e os argumentos acerca da representação especial de grupos são alvo de muitas objeções. Uma delas, particularmente relevante, presume um posicionamento que enseja diferenças sociais em vez de reduzi-las. Segundo essa objeção, a idéia de representação especial assume que um grupo de mulheres, ou de afro-americanos, de maoris, de muçulmanos, de pessoas surdas, tem um conjunto de atributos e interesses comuns que pode ser representado, o que na maioria das vezes não seria verdadeiro.

Diferenças de raça e de classe perpassam o gênero, diferenças de gênero e etnia perpassam a religião e assim por diante. Os membros de um grupo de gênero, racial etc. têm histórias de vida que os tornam muito diferentes entre si, com diferentes interesses e diferentes posicionamentos ideológi-

2. Para uma discussão das sobre as políticas de cotas de gênero na Índia, ver Meena Dhanda (19998-1990: 44-62). 
cos. Assim, o processo unificador requerido pela representação de grupos buscaria congelar relações fluidas numa identidade unificada, o que pode recriar exclusões opressivas ${ }^{3}$.

Essa objeção a políticas e propostas de representação especial de grupos, que de outra forma tendem a ser excluídos das discussões e deliberações, converge para as críticas à lógica identitária analisadas por mim alhures ${ }^{4}$. Numa versão dessa crítica, nenhum representante único poderia falar por qualquer grupo, já que os indivíduos que o compõem mantêm relacionamentos por demais entrecruzados. No entanto, as demandas por representação especial de grupos marginalizados não parecem ser afetadas por essas críticas, pois no contexto das disputas práticas muitos acreditam que tais medidas são a melhor forma de dar voz a muitas questões, análises e posições injustamente excluídas.

Busca-se aqui esclarecer o significado da representação de grupos e oferecer argumentos adicionais à idéia de que tais 142 práticas representativas diferenciadas são um importante instrumento de inclusão política. As dúvidas sobre essas práticas em parte se devem a mal-entendidos sobre a natureza da representação em seu sentido mais geral. Muitos dos discursos sobre a representação assumem implicitamente que a pessoa que representa se põe numa relação de substituição ou identidade com os muitos representados, que ele ou ela está presente por eles em sua ausência. Contrariamente a essa imagem da representação como substituição ou identificação, conceitualizo a representação como um relacionamento diferenciado entre atores políticos engajados num processo que se estende no espaço e no tempo. Considerar a temporalidade e a espacialidade mediada do processo de representação descentraliza o conceito, revelando tanto oportunidades quanto riscos políticos.

3. Esse tipo de objeção pode ser encontrado, por exemplo, em Phillips (1993); Mouffe, (1993); Cohen (1997).

4. Cf. Young, 2000, cap. 3 [N.T.]. 
Após teorizar a representação em termos gerais, volto à questão da representação de grupos. Muitas objeções às práticas da representação específica de grupos estruturalmente desfavorecidos derivam da suposição de que eles não têm um conjunto de interesses ou opiniões comuns. A partir de certos pressupostos acerca do posicionamento estrutural e da compreensão situada ${ }^{5}$, argumento que estar posicionado similarmente no campo social gera uma perspectiva social cuja inclusão na discussão pública pode ser promovida por processos de representação de grupos. Conceitualizo uma distinção entre interesses, opiniões e perspectivas e identifico seus respectivos papéis na participação política. Depois de apresentar argumentos acerca da representação especial de perspectivas sociais, que de outra forma seriam excluídas ou marginalizadas, avalio brevemente diversos canais institucionais para a efetivação dessa representação de grupos.

Antes de passar à discussão geral do significado da representação e aos argumentos acerca da representação de grupos, retomo as razões aventadas por alguns autores para afirmar que a representação é incompatível com a democracia autêntica. A primeira tarefa deste texto é rebater essas razões e explicar por que a representação não necessariamente enfraquece a participação inclusiva. Ao contrário, nas grandes sociedades de massa a representação e a participação se requerem uma à outra para que haja uma política plenamente democrática.

\section{Participação e representação}

Os democratas radicais freqüentemente desconfiam das instituições de representação política. Muitas vezes chegam a retratar a representação como algo que viola os próprios valores da democracia. Para Benjamin Barber, por exemplo, a representação "aliena a vontade política em detri-

5. Cf. ibidem. 
mento do genuíno autogoverno", "prejudica a capacidade da comunidade de atuar como um instrumento regulador da justiça" e "impede a formação de um público participativo no qual a idéia de justiça poderia se enraizar"6.

Sem dúvida, uma democracia forte deve conter em seu repertório procedimental institutos de democracia direta, tais como o do plebiscito. Além disso, uma sociedade é mais plenamente democrática quanto mais possui fóruns patrocinados pelo Estado e fomentados pela sociedade civil para discussões sobre políticas, e pelos menos alguns deles devem influenciar procedimentalmente as decisões governamentais. A posição anti-representação, no entanto, recusa-se a encarar as realidades complexas do processo democrático e erroneamente opõe a representação à participação.

A representação é necessária porque a rede da vida social moderna freqüentemente vincula a ação de pessoas e instituições num determinado local a processos que se dão 144 em muitos outros locais e instituições. Nenhuma pessoa pode estar presente em todos os organismos deliberativos cujas decisões afetam sua vida, pois eles são numerosos e muito dispersos. Ainda que as expectativas de um cidadão sejam freqüentemente desapontadas, ele espera que outros pensem em situações como a dele e as representem nos respectivos fóruns de discussão ${ }^{7}$.

Pode-se objetar que esse argumento pressupõe uma organização sociopolítica em larga escala, a qual é rejeitada pela visão da democracia direta: uma democracia sem representação deve consistir em unidades pequenas, descentralizadas e auto-suficientes. No entanto, Robert Dahl

6. Barber, Benjamin (1984: 145-146). Cf. também Hirst (1990: 42-43).

7. Para Linda Alcoff (1991: 5-32), a visão de que uma pessoa pode e deve falar apenas por si própria é uma ab-rogação de responsabilidade. Essa visão desconsidera o fato de que as vidas das pessoas são afetadas pela confluência de diversas ações distantes e que a participação institucional de uma pessoa, por sua vez, afeta as vidas de outras pessoas. 
oferece um irrefutável conjunto de argumentos sobre o fato de que mesmo essa visão da democracia direta descentralizada não pode evitar a representação. A participação igualitária de todos na deliberação política, afirma ele, só pode ocorrer em pequenos comitês. Mesmo em assembléias de umas poucas centenas de pessoas haverá uma maioria de participantes passivos, que escutam uns poucos falarem em nome de umas poucas posições e depois ponderam e votam. Para além do pequeno comitê, meras condições de tempo e interação produzem representação de facto, mas tal representação é arbitrária. Com efeito, democracias diretas freqüentemente concedem poder político a falastrões arrogantes que ninguém escolheu como representantes. Assim, mesmo em unidades de deliberação política relativamente pequenas, como as de vizinhança ou de local de trabalho, a igualdade política pode ser mais bem servida por institutos de representação formal, já que nesse caso as regras concernentes a quem está autorizado a falar por quem são públicas e há algumas normas de responsabilização (accountability). Dahl também argumenta - a meu ver plausivelmente - que no curso normal da vida social as unidades políticas pequenas e descentralizadas tendem a se expandir por meio de conquistas ou de coalizões. Tão logo há uma questão de escala, a representação também entra em jogo ${ }^{8}$.

Os críticos da democracia representativa podem objetar que essa participação ampliada, na medida em que ocorra, é alcançada em detrimento da participação cidadã no processo deliberativo: depois de eleger seus representantes, os cidadãos não são mais necessários. As instituições e a cultura de algumas democracias representativas de fato desestimulam os cidadãos a participar das discussões e deci-

8. Dahl, 1989, cap. 16. 
sões políticas. Pode-se argumentar, porém, que nesse caso elas não são propriamente representativas, pois em tais circunstâncias os representantes têm uma relação muito fraca com seus eleitores. Sob os ideais normativos da democracia comunicativa, as instituições representativas não se contrapõem à participação cidadã; antes, requerem-na para ser eficazes ${ }^{9}$. A seguir, desenvolvo uma concepção da representação como um processo de antecipação e retomada que flui entre os representantes e os representados a partir da participação destes em atividades de autorização e prestação de contas.

\section{Representação como relacionamento}

A visão de que a democracia autêntica não é compatível com representação se apóia implicitamente numa lógica identitária, ou naquilo que Jacques Derrida chama de "metafísica da presença"10. Tal visão imagina a situação de delibe-

146 ração democrática ideal como aquela em que os cidadãos estão co-presentes. Nessa imagem da democracia autêntica, os cidadãos se encontram num mesmo espaço para tomar suas decisões numa ocasião, à maneira de uma reunião de âmbito local.

Essa visão também assume uma identidade dos governantes e dos governados. Os críticos da representação a rejeitam porque as instituições representativas separam o povo do poder: aqueles que fazem as regras não são idênticos a todos aqueles que são obrigados a segui-las. Uma vez mais as palavras de Benjamin Barber são particularmente veementes: "Homens e mulheres que não são diretamente responsáveis, por meio de deliberações em comum, decisões em comum e ações em comum, pelas políticas que deter-

9. Ver Plotke, 1997: 19-34; Green, 1985, cap. 9.

10. Derrida, 1973. 
minam suas vidas em comum não são realmente livres de modo algum"11.

Nessa imagem da democracia, os representantes só poderiam expressar devidamente a "vontade do povo" se estivessem presentes por seus eleitores e agissem como estes agiriam. Nessa imagem, o representante substitui os eleitores, pondo-se com eles numa relação de identidade. Os críticos da representação corretamente observam que não é possível a uma pessoa apresentar-se no lugar de muitas outras para falar e agir como essas o fariam se estivessem presentes. É impossível captar os atributos essenciais dos eleitores, o singular bem comum que transcende a diversidade de seus interesses, experiências e opiniões. A objeção que alguns fazem à noção da representação específica de grupos marginalizados, na verdade, pode ser estendida a toda representação. Os representantes políticos geralmente têm um eleitorado amplo e diversificado em seus interesses, formações, experiências e crenças. Talvez seja até mais difícil conceber uma vontade compartilhada para os moradores de um distrito eleitoral metropolitano do que para os membros de um grupo étnico, por exemplo.

Se aceitamos o argumento de que a representação é necessária e, ao mesmo tempo, admitimos a visão de que uma deliberação democrática requer co-presença de cidadãos e de que a representação só é legítima se o representante é de algum modo idêntico aos eleitores, temos então um paradoxo: a representação é necessária mas impossível. Há uma maneira de sair desse paradoxo, que implica conceitualizar a representação sem se pautar por uma lógica identitária. Compreender seriamente a natureza descentralizada das democracias de massa em larga escala requer descartar imagens de co-presença dos cidadãos e a

11. Barber, 1984: 146. 
idéia de que os representantes devem estar presentes pelos cidadãos. Em vez disso, é preciso conceber a discussão e a deliberação democráticas como processos mediados e dispersos ao longo do espaço e do tempo. A representação política não deve ser pensada como uma relação de identidade ou substituição, mas como um processo que envolve uma relação mediada dos eleitores entre si e com um representante.

Apóio-me no conceito de différance de Derrida para formular uma outra noção de representação ${ }^{12}$. Ao passo que a metafísica da presença gera polaridades, pois visa reduzir muitas identidades numa só, pensar as entidades em termos de différance mantém-nas em sua pluralidade, sem requerer sua unificação numa identidade comum. As coisas assumem seu ser e os signos assumem seu significado a partir de seu lugar num processo de relacionamentos diferenciados. As coisas são similares sem serem idênticas e são 148 diferentes sem serem contrárias entre si, dependendo do ponto de referência e do momento em um processo. Ao enfatizar o processo e o relacionamento mais do que a substância, a différance destaca intervalos de espaço e de tempo. Oposições como substância-acidente, causa-efeito, presença-ausência e realidade-signo situam o ser autêntico numa origem, num tempo invariavelmente primordial do qual o processo presente é uma cópia derivada. Derrida propõe repensar tais oposições nos termos da idéia de vestígio, um movimento de temporalização que carrega consigo o passado e o futuro. O momento em um diálogo, este momento no ser da montanha e, como veremos, este momento na relação representativa, cada qual carrega vestígios da história dos relacionamentos que os produziram, ao passo que suas tendências atuais antecipam relacionamentos futuros.

12. Cf. Derrida, 1973. 
Conceitualizar a representação em termos de différance significa reconhecer e afirmar que há uma diferença, uma separação entre o representante e os representados. Evidentemente, nenhuma pessoa pode pôr-se por (stand for) e falar como uma pluralidade de outras pessoas. A função do representante de falar por não deve ser confundida com um requisito identitário de que o representante fale como os eleitores falariam, tentando estar presentes por eles na sua ausência. Não constitui uma crítica ao representante afirmar que ele ou ela é alguém separado e distinto dos eleitores. Ao mesmo tempo, porém, conceber a representação sob a idéia de différance significa descrever um relacionamento entre os eleitores e o representante, bem como dos eleitores entre si, no qual a temporalidade do passado e o futuro antecipado deixam vestígios nas ações de cada um deles.

Conceber a representação como um relacionamento diferenciado entre atores plurais dissolve o paradoxo posto pela situação na qual uma só pessoa representa as experiências e opiniões de muitas outras. Não há uma específica vontade do povo que possa ser representada. Uma vez que o eleitorado é internamente diferenciado, o representante não se põe por ou se reporta a uma opinião ou interesse compartilhado por todos os eleitores que ele deva expressar e defender ${ }^{13}$.

Em vez de interpretar o significado normativo da representação como o ato de propriamente pôr-se pelos eleitores, devemos avaliar o processo de representação de acordo com o caráter do relacionamento entre o representante e os eleitores. O representante inevitavelmente irá se afastar dos eleitores, mas também deve estar de alguma forma conectado a eles, assim como os eleitores devem estar conectados entre si. Os sistemas de representação, por

13. O próprio Derrida aponta para uma teorização da representação política sob a idéia de différance. Ver Derrida, 1982: 294-326. 
vezes, deixam de ser suficientemente democráticos não porque os representantes deixam de se pôr pela vontade dos eleitores, mas porque perderam a conexão com eles. Nas democracias de massa modernas, as relações entre representantes e eleitores de fato se rompem facilmente: o difícil é mantê-las.

\section{Antecipação, autorização e prestação de contas}

Em seu clássico trabalho sobre a representação, Hanna Pitkin analisa os diversos significados que se anexaram ao termo ${ }^{14}$. Para alguns autores, o que constitui um representante é o fato de que ele é autorizado a agir por um conjunto de instituições oficiais que também circunscrevem o grupo representado. Outros enfocam a demanda de que um legítimo representante deve ser responsável ou prestar contas perante aqueles que representa, pois, caso contrário, o agente que alega estar representando estará simplesmente

150 agindo por si mesmo. Pitkin retoma o debate entre aqueles que postulam o representante como um delegado que conduz o mandato de um eleitorado que ele defende e aqueles que pensam que ele deve atuar como um fiduciário (trustee) que faz avaliações independentes sobre a coisa certa a fazer sob as circunstâncias políticas. A autora argumenta que esse debate está mal colocado. Cada um dos lados estaria correto à sua maneira: a função específica de um legítimo representante consiste em fazer avaliações independentes, sabendo e antecipando o que os eleitores desejam.

A conceitualização da representação política também passa pelas seguintes questões: se os organismos representativos devem espelhar a população representada e se os interesses representados em tais organismos devem ser tomados como objetivos ou simplesmente como um produto das

14. Pitkin, 1971. 
percepções e preferências subjetivas dos eleitores. Pitkin conclui que todos esses conceitos e questões são aspectos do complexo relacionamento chamado "representação", e que tanto a teoria quanto a prática requerem a compreensão de que a atuação do representante deve permanecer nos diversos limites colocados por essas diversas questões.

A noção de representação política que apresento a seguir deve muito à de Pitkin. Sigo seus passos, ao teorizar a representação como algo que envolve tanto a autorização como a prestação de contas e ao argumentar que a dicotomia "delegado-fiduciário" é uma falsa polarização. Pitkin afirma que todas essas conceitualizações aparentemente divergentes são na verdade aspectos diversos de um complexo conjunto de instituições e práticas representativas. No entanto, ela não teoriza plenamente sobre como reuni-los. Sugiro que conceber a representação como um processo diferenciado e mediado no espaço e no tempo propicia uma forma de pensar conjuntamente esses diferentes aspectos.

Pensar a representação em termos de différance em vez de identidade significa levar em conta a sua temporalidade. A representação é um processo que ocorre ao longo do tempo e tem momentos ou aspectos distintos, relacionados entre si, mas diferentes uns dos outros. A representação consiste num relacionamento mediado entre os membros de um eleitorado, entre este e o representante e entre os representantes num organismo de tomada de decisões. $\mathrm{Na}$ qualidade de um relacionamento prolongado entre os eleitores e seus agentes, a representação oscila entre momentos de autorização e de prestação de contas: é um ciclo de antecipação e retomada entre os eleitores e o representante, no qual seus discursos e ações devem carregar vestígios de um momento a outro.

Assim, a noção aqui proposta é primordialmente normativa. Busco identificar os ideais de uma representação 
eficaz, que promova legitimidade democrática e inclusão política. De acordo com um conceito de democracia como uma questão de grau, uma boa representação é ela mesma uma questão de grau. Na próxima seção, sugiro uma medida de boa representação que considera o número de aspectos ou modos pelos quais as pessoas são representadas. Aqui, considero o alcance da conexão entre eleitores e representantes como uma medida do grau de representação. Conceitualizada como diferença, a representação necessariamente envolve distinção e separação entre representantes e eleitores. A representação é um relacionamento diferenciado entre eleitores e representantes, em que a desconexão é sempre uma possibilidade e a conexão é mantida ao longo do tempo por meio de antecipações e retomadas em momentos de autorização e prestação de contas. Dessa forma, um processo representativo é pior, na medida em que a separação tende ao rompimento, e 152 melhor, na medida em que estabelece e renova a conexão entre os eleitores e o representante e entre os membros do eleitorado.

Pitkin sugere que a autorização é um importante indício de representação. Uma pessoa que representa outras de forma oficialmente institucionalizada precisa estar autorizada a falar por elas e, talvez, a uni-las. Eleições são o meio mais comum e mais óbvio de autorizar representações, mas, às vezes, prevalecem outras formas de seleção delegatória de representantes para organismos de discussão e tomada de decisões. O modelo delegatório da responsabilidade representativa é uma interpretação da autorização. Nessa interpretação, um eleitorado é um grupo coeso e já dotado de uma vontade única que pode ser transmitida ao representante como um mandato. Tal imagem se apóia numa concepção identitária segundo a qual as muitas pessoas representadas são idênticas entre si, ao menos no sentido de que concordam com esse mandato, o 
qual o delegado pode conduzir inalterado a um organismo representativo $^{15}$.

Na verdade, porém, na maioria das situações, o eleitorado específico existe no máximo potencialmente; as próprias instituições representativas e o próprio processo de autorização é que convocam seus membros à ação ${ }^{16}$. Antecipando o momento em que os representantes se apresentarão para agir a seu mando e em seu nome, os indivíduos de um determinado eleitorado procuram uns aos outros, se organizam, discutem as questões que consideram importantes para si e convocam candidatos a responder por seus interesses. Na medida em que geralmente há um momento em que os eleitores autorizam representantes, ao fazê-lo, eles raramente comparecem para afirmar uma vontade comum. O eleitorado normalmente é amplo demais, as atividades de seus membros são variadas e dispersas demais ou sua definição e suas fronteiras são vagas demais para que se possa ensejar um momento em que o eleitorado chegue a um só tempo a uma vontade coletiva.

Em vez disso, num processo de autorização eficaz, uma esfera pública de discussão define uma agenda de questões e os principais pontos de disputa ou de luta. Para que os processos parlamentares sejam efetivamente representativos, e não meramente uma etapa em que as elites desempenhem seu papel conforme seus próprios roteiros, o processo democrático da autorização de representantes deve ser tanto participativo quanto inclusivo em sua deliberação.

15. Nancy Schwartz critica a visão que ela denomina teoria da representação como "correia de transmissão", que teria essa forma. Nessa visão, os indivíduos representados precisariam tão-somente expressar suas vontades, e o representante funcionaria como um mediador. Nem os eleitores nem o representante são ativos, e seus juízos políticos tampouco se alteram no decorrer do processo representativo. Cf. Schwartz, 1988

16. Para uma discussão sobre essa mútua constituição do eleitorado e do representante, ver Williams, 1998: 203-205. 
Como sustenta Pitkin, conceitualizar o representante puramente como um delegado com um mandato inequívoco, ou inteiramente como um fiduciário que age tão-somente de acordo com suas próprias luzes, dissolve o significado específico da atividade representativa. A representação eficaz fica entre uma coisa e outra e incorpora ambas. A responsabilidade do representante não é simplesmente expressar um mandato, mas participar das discussões e debates com outros representantes, ouvir suas questões, demandas, relatos e argumentos e com eles tentar chegar a decisões ponderadas e justas. Os diferentes grupos e segmentos da sociedade dialogam melhor em suas diferenças por meio de representantes que se encontram e ouvem uns aos outros, abertos à possibilidade de mudar suas posições.

Ao longo desses momentos de ação e avaliação independentes, o representante deve, no entanto, retomar o processo de discussão que levou à sua autorização e antecipar o 154 momento de prestação de contas perante aqueles que alega representar. O representante está autorizado a agir, mas suas avaliações estão sempre em questão. Saber se ele agiu ou não conforme aquela autorização é uma questão posposta a um momento ulterior, quando ele vier a prestar contas de suas ações aos representados. O representante age por si próprio, mas antecipando esse momento. Uma vez que não há mandato autorizado para várias decisões, a representação é mais forte quando carrega os vestígios da discussão que levou à autorização ou quando, de outra forma, se justifica persuasivamente numa prestação de contas pública.

No processo de convocação dos representantes para prestar contas sobre as decisões tomadas, os cidadãos continuam a se constituir como uma base eleitoral e voltam a se engajar no debate, discutindo sobre a adequação e as implicações daquelas decisões. Essa formação de opinião renovada pode carregar vestígios do processo de autorização, mas agora tem novos elementos, na medida em que 
anteriormente os eleitores não sabiam exatamente como as questões seriam formuladas no organismo representativo, quais expressões, solicitações e argumentos seriam ali apresentados. A responsabilidade do representante não consiste apenas em relatar aos cidadãos como cumpriu o mandato por eles autorizado ou como serviu aos seus interesses, mas também em persuadi-los da adequação de suas avaliações ${ }^{17}$.

$\mathrm{Na}$ maioria das democracias existentes, o momento da prestação de contas é mais fraco que o da autorização. Em muitos sistemas de representação, a única forma de efetivar a prestação de contas é a reautorização por meio da reeleição. O ciclo que volta à autorização é de fato importante para motivar a prestação de contas, mas uma democracia comunicativa forte requer também alguns processos e procedimentos mediante os quais os eleitores convoquem os representantes a prestar contas para além dos momentos de reautorização. Assim como a autorização, a prestação de contas deve ocorrer tanto por meio de instituições oficiais como na arena pública da associação civil independente. Todas as democracias representativas existentes podem ser aperfeiçoadas por procedimentos e fóruns complementares por meio dos quais os cidadãos discutam entre si e com os representantes suas avaliações acerca das políticas que esses últimos apoiaram. Meios oficiais de prestação de contas distintos das campanhas eleitorais podem incluir conselhos de supervisão, comissões de estudos de implementação e audiências participativas periódicas que acompanhem os processos de produção de políticas. Esferas públicas da sociedade civil podem aprofundar a responsabilização mediante questionamentos, elogios, críticas e avaliações independentes.

17. Para Amy Gutmann e Dennis Thompson (1996, cap. 4), a prestação de contas, incluindo a dos representantes perante os eleitores, é um dos três princípios procedimentais da democracia deliberativa. A meu ver, no entanto, eles enfatizam a prestação de contas do representante em detrimento da explanação das razões que tiveram para eventualmente agir em discordância. 
O principal problema normativo da representação é a ameaça de desconexão entre o representante único e os muitos que ele ou ela representa. Quando os representantes se tornam muito afastados, os eleitores perdem a percepção de que exercem influência sobre a produção de políticas, desafeiçoam-se e se abstêm da participação. Estabelecer e manter processos de representação legítimos e inclusivos impõe responsabilidades tanto para os representantes como para os cidadãos. Estes precisam estar dispostos e aptos a mobilizar uns aos outros para participar ativamente tanto do processo de autorização quanto do de prestação de contas. Os representantes devem ouvir essas discussões públicas e as diversas demandas, permanecer conectados com os eleitores e expor as razões de suas ações e avaliações em termos que retomem aquelas discussões. Essa mobilização e essa conectividade podem ser promovidas ou obstadas pelo desenho das instituições representativas.

156 Assim, posso agora trocar em miúdos a proposição de que numa democracia comunicativa inclusiva a representação e a participação não são excludentes, mas requerem uma à outra. As instituições representativas contribuem para organizar as discussões e as tomadas de decisão políticas ao introduzir procedimentos e uma pertinente divisão do trabalho. Dessa forma, os cidadãos têm objetivos em torno dos quais podem se organizar entre si e tomar parte em discussões, críticas e avaliações antecipatórias e retrospectivas. Sem essa participação cidadã a conexão entre representantes e eleitores fica mais sujeita a romper-se, fazendo do representante um agente da elite. De sua parte, os representantes devem responder a esses processos participativos. As esferas públicas da sociedade civil são importantes arenas para a participação cidadã e contribuem para manter tais conexões ${ }^{18}$.

18. No Capítulo 5 de Inclusion and democracy, a autora discute especificamente as esferas públicas da sociedade civil [N.T.]. 


\section{Modos de representação}

Se o representante não deve ser pensado como um substituto daqueles que representa, como já sugeri, tampouco se deve assumir que ele possa ou deva expressar e cumprir algum tipo de vontade unívoca da sua base eleitoral. O representante não pode retratar nem a identidade de qualquer outra pessoa nem a identidade coletiva de um eleitorado. É inevitável que haja uma diferença e uma separação entre representante e eleitores, o que continuamente põe em questão o modo e o grau em que os eleitores participam do processo que leva à produção de políticas. Não obstante, nas sociedades modernas a representação é tanto necessária quanto desejável. Em vez de desvalorizar a representação enquanto tal, os democratas participativos e radicais deveriam avaliar em que medida os processos de autorização e prestação de contas existem, são independentes e suscitam a participação ativa e inclusiva do eleitorado no debate público.

Sugiro aqui uma outra medida dos graus de democracia, que consiste em saber se as pessoas estão conectadas, por meio de relacionamentos de autorização e prestação de contas, com uma pluralidade de representantes que correspondem a diferentes aspectos de suas vidas. A suposição de que os representantes devem ser de alguma forma idênticos aos eleitores comporta implicitamente o requisito impossível de que uma pessoa só pode ser representada se tudo a seu respeito potencialmente tiver voz no processo político. Uma vez que o representante é necessariamente diferente dos eleitores, uma democracia é melhor ou pior conforme o quão bem estejam conectadas essas posições diferenciadas. A democracia também pode ser fortalecida mediante a pluralização dos modos e espaços de representação. Os sistemas de representação política não podem fazer que os indivíduos estejam presentes em suas individualidades: devem representar aspectos da experiência de vida, da identidade, das crenças ou atividades mediante os quais uma pessoa tem afinidade 
com outras. Esses aspectos ou afinidades são potencialmente numerosos. Proponho aqui distinguir três modos gerais pelos quais uma pessoa pode ser representada: interesses, opiniões e perspectivas. Num contexto político específico, uma pessoa pode ser representada de diversas maneiras em cada uma dessas modalidades. A explanação sobre a representação da perspectiva, em particular, provê argumentos para a representação especial de grupos sociais oprimidos ou desfavorecidos, na medida em que evita o problema de atribuir opiniões ou interesses comuns a todos os membros desses grupos.

O que dou a entender quando digo que me sinto representado no processo político? Há muitas respostas possíveis para essa pergunta, mas três delas me parecem se destacar como as mais importantes. Primeiramente, sinto-me representado quando alguém está cuidando de interesses que reconheço como meus e que compartilho com algumas outras pessoas. Em segundo lugar, é importante para 158 mim que os princípios, valores e prioridades que penso deveriam nortear as decisões políticas sejam verbalizados nas discussões que as deliberam. Por fim, sinto-me representado quando pelo menos algumas dessas discussões e deliberações sobre políticas captam e expressam o tipo de experiência social que me diz respeito, em razão da minha posição num grupo social e da história das relações desse grupo social. Discutirei interesses e opiniões apenas em linhas gerais, visto que são temas já amplamente discutidos na teoria política. Dedicarei mais atenção à representação das perspectivas, uma vez que essa idéia é menos familiar.

\section{Interesses}

Defino "interesse" como aquilo que afeta ou é importante para os horizontes de vida dos indivíduos ou para as metas das organizações. Um agente individual ou coletivo tem interesse naquilo que é necessário ou desejável para que sejam alcançados os fins que ele almeja. Isso inclui tanto os recur- 
sos materiais quanto a habilitação para exercer capacidades, por exemplo, de expressão cultural, de influência política, de interferência nas decisões econômicas. Concebo aqui os interesses como auto-referentes e como algo diverso de idéias, princípios e valores. Estes podem ajudar a definir os fins que uma pessoa estabeleceu para si mesma, enquanto os interesses definem os meios para alcançar esses fins.

Os interesses freqüentemente conflitam não apenas entre agentes, mas também nas ações de um único agente. Ao procurar obter os recursos de que precisam para realizar uma variedade de fins, os agentes tendem a descobrir que alguns desses recursos são relativamente escassos. Às vezes, a obtenção de certos recursos por um agente implica diretamente que ele impeça um outro agente de obter os meios necessários para perseguir seus fins. No entanto, é importante notar que os interesses não necessariamente conflitam entre si. A busca de fins em sociedade e o arranjo dos instrumentos políticos que viabilizam essa busca não precisam necessariamente estar estruturados como um relacionamento de soma zero entre os agentes.

A representação do interesse é corrente na prática política, e talvez haja mais teoria da representação do interesse do que de qualquer outro tipo de representação. Não pretendo retomar aqui a vasta literatura sobre os grupos de interesse e os meios pelos quais eles podem obter influência política. Apenas assinalo que faz parte do processo de livre associação na democracia comunicativa que as pessoas tenham liberdade de pressionar, politicamente, por políticas que atendam a seus interesses e de se organizar com outras pessoas que tenham interesses similares a fim de obter influência política.

\section{Opiniões}

Defino “opiniões" como os princípios, valores e prioridades assumidos por uma pessoa na medida em que fundamentam e condicionam seu juízo sobre quais políticas devem 
ser seguidas e quais fins devem ser buscados. Trata-se da esfera primária daquilo que Anne Phillips chama de "política das idéias"19, que está no centro de muitas das discussões contemporâneas acerca do pluralismo. A discussão de Rawls sobre os princípios e os problemas do liberalismo político, por exemplo, concentra-se na questão dos sistemas plurais de idéias e crenças nas sociedades modernas, interrogando o quanto eles influenciam legitimamente a vida política e como pessoas com diferentes crenças e opiniões podem manter um organismo sociopolítico articulado ${ }^{20}$.

Entendo por “opinião” todo juízo ou crença sobre como as coisas são ou devem ser e os critérios políticos que daí se seguem. Opiniões podem ser religiosas - ou derivar de motivações religiosas - ou podem ser culturalmente baseadas numa visão de mundo ou na história de determinadas práticas sociais. Podem se basear em sistemas de conhecimento disciplinares - consistindo, por exemplo, em opini-

160 ões políticas derivadas de certas premissas da economia neoclássica -, ou num conjunto de princípios normativos, tais como os do libertarianismo ou da ecologia radical. Embora eu duvide que todas as opiniões da maioria das pessoas sobre questões públicas derivem de uma única "doutrina abrangente" (nos termos de Rawls), suponho que a maioria das pessoas paute seus juízos sobre determinados temas sociais e políticos por certos valores, prioridades e princípios que elas aplicam a outros tantos temas, se não a todos. Opiniões certamente são contestáveis, e freqüentemente algumas podem se mostrar mais bem fundamentadas que outras. No entanto, uma democracia comunicativa requer a

19. Phillips, 1995.

20. Rawls, 1993. Com o termo "opinião", no entanto, não necessariamente concebo algo tão circunscrito e fundamental quanto aquilo que Rawls denomina "doutrina abrangente" (comprehensive doctrine), em parte porque duvido que a maioria das pessoas nas sociedades modernas paute seus critérios políticos por uma única doutrina abrangente (ver Young, 1995: 181-190). 
livre expressão e o questionamento de opiniões, bem como uma ampla representação de opiniões em discussões que levem a decisões políticas.

Os partidos políticos são o veículo mais comum para a representação de opiniões. Os partidos freqüentemente elaboram programas que, menos que expressar os interesses de um determinado eleitorado, organizam os temas políticos do dia segundo princípios, valores e prioridades que eles se propõem a representar de forma geral. No entanto, associações menores ou mais especializadas também podem representar opiniões na vida pública e influenciar as políticas públicas. A teoria dos grupos de interesse tradicionalmente tem tratado essas associações como mais um tipo de grupo de interesse, o que é um tanto inócuo para muitos efeitos. Creio, no entanto, que é importante fazer uma distinção genérica entre associações políticas motivadas por um interesse instrumental e associações políticas motivadas por um comprometimento com crenças e valores. Enquanto a primeira forma de motivação é autocentrada, mesmo que autocentrada num grupo, a segunda, freqüentemente, se assume como imparcial ou mesmo altruísta.

\section{Perspectivas}

Tenho argumentado que os grupos sociais estruturais não devem ser pensados de acordo com uma lógica substancial, que os definiria segundo um conjunto de atributos que seriam comuns a todos os seus membros e constituiriam suas identidades, mas a partir de uma lógica mais relacional, em que os indivíduos seriam compreendidos como posicionados nas estruturas dos grupos sociais, sem que estas determinem suas identidades ${ }^{21}$. Contrariamente àqueles que consideram que políticas de diferenciação de

21. Cf. Young, 2000, cap. 3 [N.T.]. 
grupos apenas criam divisões e conflitos, argumento que a diferenciação de grupos propicia recursos para um público democrático comunicativo que visa estabelecer a justiça, uma vez que pessoas diferentemente posicionadas têm diferentes experiências, histórias e compreensões sociais, derivadas daquele posicionamento. A isso chamo perspectiva social.

Conforme suas posições sociais, as pessoas estão sintonizadas com determinados tipos de significados e relacionamentos sociais, com os quais outras pessoas estão menos sintonizadas. Eventualmente estas últimas não estão posicionadas sequer de forma a ter consciência deles. A partir das suas posições sociais as pessoas têm compreensões diferenciadas dos eventos sociais e de suas conseqüências. Uma vez que suas posições sociais derivam parcialmente das construções que outras pessoas fazem delas, assim como das construções que elas fazem de outras pessoas em diferentes posições, 162 pessoas diferentemente posicionadas podem interpretar de modos diferentes o significado de ações, eventos, regras e estruturas. Assim, as posições sociais estruturais produzem experiências particulares, relativas ao posicionamento, e compreensões específicas dos processos sociais e de suas conseqüências. Cada grupo diferentemente posicionado tem uma experiência ou um ponto de vista particular acerca dos processos sociais precisamente porque cada qual faz parte desses processos e contribui para produzir suas configurações. É especialmente quando estão situadas em diferentes lados das relações de desigualdade estrutural que as pessoas entendem essas relações e suas conseqüências de modos diferentes.

Seguindo a lógica metafórica da diferenciação de grupos como produto de posições diferentes no campo social, a idéia da perspectiva social sugere que agentes que estão "próximos" no campo social têm pontos de vista semelhantes sobre esse campo e sobre o que ocorre em seu âmbito, 
enquanto aqueles que estão socialmente distantes tendem a ver as coisas de modo diverso. Embora diferentes, essas perspectivas sociais não são necessariamente incompatíveis. Cada perspectiva social é particular e parcial com relação ao campo social em seu todo, e, a partir de cada perspectiva, alguns aspectos da realidade dos processos sociais são mais visíveis que outros.

Assim, uma perspectiva social não comporta um conteúdo específico determinado. Nesse sentido, a perspectiva difere do interesse e da opinião. A perspectiva social consiste num conjunto de questões, experiências e pressupostos mediante os quais mais propriamente se iniciam raciocínios do que se extraem conclusões. As críticas ao essencialismo apontam corretamente que pessoas, a princípio pertencentes ao mesmo grupo social, freqüentemente têm interesses e opiniões diferentes e mesmo conflitantes. Pessoas que têm uma perspectiva semelhante sobre processos e temas sociais - sobre as normas da interação heterossexual, por exemplo - freqüentemente têm interesses ou opiniões não obstante diferentes, já que raciocinam de modos diferentes a partir daquilo que experienciam, ou têm metas e projetos diferentes.

A perspectiva é um modo de olhar os processos sociais sem determinar o que se vê. Dessa forma, duas pessoas podem compartilhar uma perspectiva social e não obstante experienciar seus posicionamentos de maneiras diferentes, na medida em que estão voltadas a diferentes aspectos da sociedade. Compartilhar uma perspectiva, porém, propicia a cada uma delas uma afinidade com o modo como a outra descreve o que experiencia, uma afinidade que as pessoas posicionadas diferentemente não experienciam. Essa menor afinidade não implica que essas últimas não possam compreender uma descrição de um aspecto da realidade social a partir de uma outra perspectiva social; significa apenas que é mais difícil compreender a expressão 
de perspectivas sociais diferentes do que aquelas que são compartilhadas $^{22}$.

A perspectiva social é o ponto de vista que os membros de um grupo mantêm sobre os processos sociais em função das posições que neles ocupam. As perspectivas podem ser vivenciadas de um modo mais ou menos autoconsciente. As experiências culturais de povos ou de grupos religiosos diferenciados, bem como de grupos que reagem a uma história de injustiças ou de opressão estrutural, freqüentemente lhes conferem interpretações refinadas acerca de suas próprias situações e de suas relações com outros grupos. A perspectiva pode se revelar em histórias e em canções, em brincadeiras e em jogos de palavras, assim como em formas de expressão mais assertivas e analíticas. Exploremos um exemplo.

Por mais de cinqüenta anos o semanário Pittsburgh Courier foi um veículo muito importante para os afro-ameri164 canos da cidade de Pittsburgh, mas também de muitas outras partes dos Estados Unidos ${ }^{23}$. Creio que esse periódico ilustra muito bem a diferença entre perspectiva, de um lado, e interesse e opinião, de outro. Os eventos e as polêmicas nele noticiados mostram a pluralidade de interesses - nem sem-

22. Muitos autores têm recorrido a uma idéia semelhante à da perspectiva social para descrever modos de olhar socialmente situados (ver Minow, 1990: 60-70). Melissa Williams (1998, esp. cap. 4) invoca uma idéia de perspectiva social em seus argumentos acerca da representação de grupos, e sua noção do modelo de representação "vocal" ressoa a idéia da perspectiva social. Thomas Christiano (1996: 189-90) também argumenta que grupos sociais diversos freqüentemente têm pontos de vista diferentes sobre questões políticas e sociais dos quais todos se beneficiam quando são vocalizados. Kristin R. Monroe e Lina H. Kreidi (1997: 19-43) desenvolvem uma idéia de perspectiva social um tanto diferente, mas operacionalmente similar, para teorizar sobre a psicologia social do característico grupo dos fundamentalistas islâmicos em sociedades ocidentais predominantemente seculares.

23. O semanário foi fundado em 1910 pelo advogado e jornalista Robert L. Vann. Adquirido pelo Grupo Sengstacke em 1966, passou a circular como New Pittsburgh Courier, tal como se denomina até hoje [N.T.]. 
pre compatíveis - dos afro-americanos de Pittsburgh e de toda parte. Nas páginas de opinião encontra-se uma gama ideológica que vai do libertarianismo de extrema-direita ao socialismo de extrema-esquerda, do separatismo econômico ao integracionismo liberal. A despeito dessa variedade de interesses e opiniões, não é difícil identificar como o Pittsburgh Courier expressa uma perspectiva afro-americana. Nota-se que a maioria dos eventos noticiados e analisados envolve os afro-americanos como protagonistas e se passa em locais e instituições majoritariamente afro-americanos ou especificamente associados a eles. Ao repercutir eventos locais ou nacionais não especificamente identificados com os afro-americanos, as matérias normalmente discutem ou enfatizam questões particularmente pertinentes aos temas e experiências mais específicos aos afro-americanos ${ }^{24}$.

Pode-se objetar que a idéia de uma perspectiva afroamericana ou uma perspectiva de gênero está tão sujeita a críticas quanto a idéia de um único interesse de grupo. Falar de uma perspectiva nativo-americana não seria um reducionismo tão impróprio quanto falar de um interesse nativo-americano? Por certo, cada pessoa tem sua própria história irredutível, o que lhe confere uma perspectiva ou uma percepção social única. No entanto, devemos evitar a visão individualista que concluiria desse fato que todo e qualquer discurso sobre posicionamento social estrutural e situação social definida por grupos é equivocado, incoerente ou inútil. Faz sentido dizer que pessoas da classe trabalha-

\footnotetext{
24. Lynn Sanders invoca a idéia de perspectiva social no contexto da comunicação democrática, em particular as diferentes perspectivas expressas por negros e brancos nos Estados Unidos (Sanders: 347-376). Com Donald Kinder, ela documentou as perspectivas desses grupos estruturalmente diferenciados acerca da política norte-americana (Kinder, 1996). Mediante uma síntese de diversos estudos empíricos, Jennifer Hochschild também documenta que afro-americanos e brancos têm compreensões diferentes de muitos aspectos da sociedade norte-americana, mostrando ainda diferenças de perspectiva de classe no interior de cada grupo racial acerca das oportunidades e dos problemas sociais (Hochschild, 1995).
} 
dora sem especialização profissional têm vulnerabilidades e oportunidades previsíveis em função de suas posições na estrutura ocupacional. A idéia de perspectiva busca captar a sensibilidade da experiência do posicionamento num grupo, sem especificar um conteúdo unificado para aquilo que a percepção vê. O posicionamento social, produzido por relações com outras posições estruturais e por processos sociais que resultam em conseqüências não planejadas, apenas proporciona uma experiência e uma perspectiva nos termos das quais determinados eventos e questões sociais são interpretados: elas não fazem a interpretação. Assim, podemos muito bem encontrar pessoas que têm uma perspectiva social semelhante, mas que fazem interpretações diferentes de uma mesma questão. A perspectiva é uma abordagem da maneira de olhar eventos sociais, a qual condiciona, mas não determina o que se vê.

Suponha-se que aceitemos essa noção de que indiví166 duos posicionados de modo similar no campo social têm uma perspectiva de grupo similar sobre a sociedade. O que isso implica para os indivíduos, já que estão posicionados a partir de diversas relações entre grupos diferenciados? Uma vez que em sociedades complexamente estruturadas os indivíduos estão multiplamente posicionados, eles interpretam a sociedade a partir de uma multiplicidade de perspectivas sociais de grupos. Algumas destas podem se entrecruzar e constituir uma perspectiva híbrida diferenciada - por exemplo, uma perspectiva das mulheres negras ou uma perspectiva dos jovens da classe trabalhadora. Os indivíduos podem se mover em torno de perspectivas que lhes estão disponíveis conforme as pessoas com as quais interagem ou conforme o aspecto da realidade social ao qual se voltam. As múltiplas perspectivas a partir das quais as pessoas podem ver a sociedade podem reforçar e enriquecer umas às outras ou então pode ser impossível considerar uma sem confundi-la com outra, como na figura justaposta do pato- 
coelho. As perspectivas disponíveis a uma pessoa podem ser incomensuráveis, de modo que essa multiplicidade pode produzir ambigüidades ou confusões na sua experiência e compreensão da vida social, ou então ajudá-la a formar uma imagem compósita dos processos sociais. A disponibilidade de múltiplas perspectivas propicia recursos para que cada pessoa tome distância de qualquer uma delas e para que se comunique com pessoas com as quais não compartilha perspectivas.

Referindo-se a uma distinção entre interesses, opiniões e perspectivas que formulei anteriormente, Melissa Williams objeta que perspectivas e interesses não podem ser distinguidos nitidamente: "Meu entendimento das relações entre perspectivas e interesses é antes o de que uma perspectiva de grupo compartilhada contribui para definir os limites dentro dos quais são possíveis diferentes interpretações dos interesses" 25 . É proveitoso conceber a perspectiva social como algo que contribui para estabelecer um quadro de referências para as interpretações, pois isso de fato ajuda os indivíduos a ponderar sobre aquilo que acham ser do seu interesse. No entanto, ao teorizá-la dessa forma, é preciso reconhecer que indivíduos similarmente posicionados nas estruturas sociais por vezes descobrem que há muitos interesses que eles não compartilham. Representar um interesse ou uma opinião geralmente envolve promover certos desdobramentos específicos no processo de tomada de decisões, ao passo que representar uma perspectiva geralmente significa promover certos pontos de partida para a discussão. A partir de uma determinada perspectiva social um representante coloca certos tipos de questões, relata certos tipos de experiência, retoma uma determinada linha de narrativa histórica ou expressa um certo modo de olhar as posições de outrem. Isso

25. Williams, 1998: 171. Cf. Young,1997. 
contribui decisivamente para a inclusão de diferentes pessoas no processo de tomada de decisões e chama a atenção para possíveis efeitos das políticas propostas sobre os diferentes grupos. No entanto, expressar uma perspectiva quase nunca significa inferir uma conclusão sobre resultados.

Darei um outro exemplo pra ilustrar a expressão da perspectiva. Em 1992, o senador norte-americano Robert Packwood foi acusado de assédio sexual por várias de suas assessoras. Quando as acusações vieram à tona, muitos senadores se mostraram relutantes em realizar audiências com as partes envolvidas. Packwood tinha uma eminente folha de serviço no Senado, e muitos de seus colegas assumiram a atitude de que aquelas acusações escandalosas não mereciam que se formasse uma comissão parlamentar para apurar o caso. Diante disso, senadoras e também deputadas convocaram uma conferência com a imprensa para exigir que o Senado apurasse as acusações contra Packwood 168 e eventualmente aplicasse as sanções éticas cabíveis. Essas mulheres tinham muitos interesses divergentes, não cultivavam os mesmos valores políticos e não confluíam em suas opiniões acerca da culpabilidade de Packwood. Seu propósito era influenciar a agenda do Senado e, ao fazê-lo, expressaram uma mesma perspectiva sobre a importância e a gravidade das acusações de assédio sexual, uma perspectiva que muitos de seus colegas do sexo oposto pareciam não compreender, pelo menos de início.

Interesses, opiniões e perspectivas são, portanto, três importantes aspectos das pessoas que podem ser representados. Não penso que esses três aspectos esgotem os modos pelos quais as pessoas podem ser representadas. Certamente, há outros modos de representação possíveis, mas creio que esses três sobressaem quando falamos de representação da política contemporânea e quando discutimos os problemas conceituais e práticos colocados à representação de grupos. Ademais, nenhum desses aspectos é redu- 
tível aos outros. Eles são logicamente independentes, no sentido de que, a partir de uma perspectiva social geral, não se pode imediatamente inferir um conjunto de interesses ou de opiniões.

Diferentemente dos interesses e das opiniões, as perspectivas sociais não podem ser facilmente pensadas como conflitantes. Reunidas, elas geralmente não se anulam entre si; antes, oferecem questões adicionais e compreensões sociais mais plenas. No entanto, as perspectivas freqüentemente podem ser incomensuráveis. Um relato dos Estados Unidos do pós-guerra a partir da perspectiva das pessoas que agora estão em seus 80 anos de idade não pode ser feito na mesma linguagem e com os mesmos pressupostos de um relato feito a partir da perspectiva de pessoas que agora estão em seus 20 anos.

\section{Representação de grupos marginalizados}

Poucos negariam que os membros de grupos sociais estruturais menos privilegiados estão sub-representados na maioria das democracias contemporâneas. A desigualdade socioeconômica estrutural com freqüência produz desigualdade política e exclusão relativa das discussões políticas influentes ${ }^{26}$. Assim, as pessoas pobres e da classe trabalhadora freqüentemente não têm seus interesses e perspectivas tão bem representados quanto os das pessoas das classes média e alta. Na maior parte dos sistemas políticos, as mulheres ocupam uma pequena proporção dos cargos públicos eleitos, bem como estão relativamente pouco presentes nas posições de poder e influência na vida pública e privada de modo geral. Grupos culturais minoritários e aqueles situados em posições raciais desvalorizadas também costumam carecer de voz política efetiva. Muitos

26. Cf. Young, 2000, cap. 1 [N.T.]. 
consideram incorreta essa exclusão ou marginalização política de grupos e indivíduos subordinados, pois isso frustra as promessas de igualdade política e de oportunidades que estão na base dos princípios democráticos. Tais juízos sobre a injustiça da desigualdade política podem ser mobilizados para romper o círculo mediante o qual a democracia política formal tende a reproduzir a desigualdade social. Propiciar maior inclusão e influência aos grupos sociais subrepresentados pode contribuir para que uma sociedade enfrente e reduza a desigualdade social estrutural ${ }^{27}$.

Uma forma importante de promover maior inclusão de membros dos grupos sociais sub-representados se dá por meio de dispositivos políticos destinados especificamente a aumentar a representação de mulheres, pessoas da classe trabalhadora, minorias raciais ou étnicas, castas desfavorecidas etc. Assim, esquemas como cotas em listas partidárias, representação proporcional, cadeiras parlamentares reservadas 170 e delimitação de distritos eleitorais especiais, entre outros, têm sido propostos e implementados para promover a representação de grupos. Os movimentos sociais cada vez mais demandam formas de representação de grupos não apenas nas legislaturas, mas também em diversos tipos de comissões e conselhos, em instâncias diretivas das empresas privadas e em órgãos estatais. Embora as propostas de representação de grupos quase sempre sejam controversas, as exclusões estruturais que motivam tais propostas parecem permanecer em muitas sociedades. No entanto, como aponta Anne Phillips, a representação específica de grupos que de outra forma permaneceriam marginalizados não é uma conseqüência imediata do compromisso com a igualdade política ${ }^{28}$ : são necessários argumentos normativos adicionais.

27. Melissa Williams (1998: 194) apresenta uma noção parecida da conexão potencial entre normas de representação e desigualdade estrutural.

28. Phillips,1995: 33-36. 
Muitos duvidam que a representação específica de grupos sociais promova justiça ou tenha pertinência. Alguns afirmam que os indivíduos devem contar diretamente com as instituições políticas, sem a mediação de grupos, e que a agregação de votos individuais em distritos eleitorais para eleger representantes é a única forma de implementar tal individualismo político ${ }^{29}$. Outros, como já apontei, consideram a representação de grupos suspeita de uma essencialização enviesada e equivocada.

Diversos teóricos fazem objeções àquilo que se chama de representação "descritiva” ou representação como "espelho”. Uma concepção dessa imagem de representação afirma que um organismo representativo deve parecer uma cópia do organismo social em que se insere, de modo que deve conter membros dos grupos sociais óbvios na proporção em que eles são encontrados na sociedade em geral. Pitkin argumenta que tal concepção considera o ato de representar simplesmente como uma forma de "substituir" ou "pôr-se por", em vez de pensá-lo como uma atividade ${ }^{30}$. Além do mais, se para que os parlamentares sejam propriamente representativos tudo o que importa é que tenham certos atributos específicos, então uma amostragem aleatória pode ser um meio mais efetivo de selecionar representantes do que a eleição ${ }^{31}$.

29. Cf. Schwartz, 1988.

30. Pitkin, 1971: 90.

31. Cf. Pitkin, 1971: 73; Kymlicka, 1996: 139. Isso soa como um argumento reductio ad absurdum, dirigido contra o uso de técnicas de amostragem com o propósito de formar diversos grupos; mas tais métodos não são obviamente disparatados. James Fishkin (1995), por exemplo, utiliza amostragem aleatória em suas pesquisas de opinião sobre deliberação. Ele argumenta que essa é uma forma eficiente e razoavelmente confiável de reproduzir a multiplicidade de perspectivas sociais que eu postulo como necessária para uma deliberação informada, e pode ter razão nisso. No entanto, os grupos que ele compõe não são propriamente político-representativos, precisamente porque não têm conexão institucional ou ativa com uma base eleitoral. 
No entanto, muitos dos que advogam a representação específica de mulheres, ou de afro-americanos, ou de classes ou de aborígines, achariam absurda a sugestão de que atributos físicos ou de pertencimento em si mesmos poderiam fundamentar a representação de determinadas pessoas por outras com atributos semelhantes. Em vez disso, argumentam eles, mulheres, aborígines etc. têm experiências semelhantes que apenas os membros de seus próprios grupos podem compreender com o mesmo imediatismo. Para outros, contudo, justificar a representação de grupos em termos de experiências, interesses ou opiniões supostamente compartilhadas por todos os membros do grupo obscurece as diferenças internas deste e erroneamente reduz todos os membros a uma essência comum, de modo que os grupos se tornariam de tal forma distintos uns dos outros que lhes seriam impossíveis o entendimento e a cooperação em suas diferenças ${ }^{32}$.

172 A teoria da representação que apresentei aqui pode responder a algumas dessas questões sobre a representação de grupos. Em qualquer forma que assuma, a representação de grupos não deve ser concebida somente por referência a atributos compartilhados por pessoas, assim como não consiste na manifestação de algum conjunto de opiniões, interesses ou experiências que todos os membros do grupo compartilhem. Como já ressaltei, uma tal interpretação segue uma lógica identitária, em vez de conceitualizar a representação como um processo diferenciado de relações entre o representante e os representados.

Por outro lado, essa teoria rejeita um pressuposto que está implícito em muitas das objeções à representação de grupos: o de que a participação de uma pessoa num organismo sociopolítico em larga escala pode ser de algum modo

32. Cf. Kymlicka, 1996: 139; Phillips, 1995, cap. 2. 
individualizada. Todos os sistemas e instituições de representação agrupam indivíduos de acordo com certos princípios, e nenhum deles é inocente ou neutro ${ }^{33}$. Qualquer forma ou sistema de representação coloca o problema de haver "um só para muitos", e a meu ver esse problema é mais bem enfrentado pelos relacionamentos ativos de autorização e prestação de contas entre representantes e representados. Quer o princípio da configuração da base eleitoral seja o local de residência, a crença, o interesse financeiro, o interesse organizacional ou ocupacional ou a posição num grupo social, os membros do eleitorado são mais bem representados quando se organizam para discutir suas concordâncias e diferenças uns com os outros e com os representantes.

Antes de mais nada, toda base eleitoral é internamente diferenciada e tem de se organizar na relação com um representante. Além disso, os indivíduos são mais bem representados quando os organismos de representação são plurais e quando os indivíduos têm relacionamentos plurais com os representantes, tanto nas associações civis quanto nas organizações políticas. A distinção aqui delineada entre modos de representação por opiniões, interesses e perspectivas descreve tal pluralização. A noção de representação da perspectiva, em particular, busca responder àquelas objeções à representação de grupos que afirmam que os grupos sociais não podem ser definidos por interesses ou opiniões comuns. Na medida em que os grupos sociais se distinguem por relações estruturais, particularmente relações estruturais de privilégio e de desvantagem, e na medida em que as pessoas se posicionam similarmente naquelas estruturas, então elas têm perspectivas similares tanto sobre sua própria posição na sociedade quanto sobre outras posições.

33. Cf. Williams, 1998: 26. 
Assim, os argumentos acerca da representação especial de grupos sociais estruturais que de outra forma permaneceriam sub-representados invocam a contribuição que tais práticas representativas podem e devem dar à discussão e ao engajamento políticos inclusivos junto a grupos diferentes e com os quais possa haver conflitos ${ }^{34}$. Em primeiro lugar, quando há uma história de exclusão ou marginalização de certos grupos da influência política, os membros desses grupos tendem a se desafeiçoar do processo político: podem ficar apáticos ou se recusar terminantemente a se engajar com outros para tentar resolver problemas compartilhados. Sob tais circunstâncias, a representação específica de grupos desfavorecidos estimula a participação e o engajamento ${ }^{35}$.

Em segundo lugar, onde certos grupos sociais estruturais lograram dominar as discussões e as decisões políticas, suas perspectivas sociais geralmente definem as prioridades políticas, os termos nos quais elas são discutidas e a noção 174 de relações sociais que enquadra a discussão. Ao mesmo tempo, essas perspectivas freqüentemente não são reconhecidas como um modo específico de olhar as questões em pauta, mas tomadas como neutras e universais. A representação especial de perspectivas sociais que de outra foram

\footnotetext{
34. O que se segue amplia e revisa argumentos que apresentei num trabalho anterior (Young, 1990, cap. 6). Ainda que nesse trabalho eu não tenha pretendido restringir o lugar da representação de grupos às legislaturas nem especificar que essa representação deva ser feita por meio de cadeiras reservadas, muitos interpretaram os argumentos ali apresentados como se implicassem isso (cf. Kymlicka, 1996: 141; Phillips, 1995: 54; Ryden, 1996: 88-91). Assim, aqui exponho mais explicitamente as questões relativas aos lugares e significados da representação de grupo. Ao fazê-lo, fundamento ainda um argumento ali colocado que pareceu ser particularmente controverso: o de que os grupos desfavorecidos devem ter poder de veto sobre as decisões acerca de questões que mais especificamente lhes afetem.

35. Melissa Williams (1998, cap. 5) refere-se a isso como um argumento de "confiança" acerca da representação especial de grupos marginalizados. Jane também invoca o desenvolvimento da confiança como um argumento para aquilo que ela chama de "representação descritiva" (Mansbridge, 1997: 628-657).
} 
seriam excluídas revela a parcialidade e a especificidade das perspectivas politicamente presentes ${ }^{36}$.

Por fim, a representação especial de grupos marginalizados traz à discussão e à deliberação políticas as compreensões situadas que mencionamos anteriormente. Em virtude de seus posicionamentos sociais, os membros dos grupos estruturalmente diferenciados freqüentemente têm compreensões diferentes acerca das causas dos problemas e conflitos e dos possíveis efeitos das soluções propostas. Cada grupo tem percepções diferentes sobre os demais, e compreensões diferentes sobre a história e a configuração atual das relações sociais. Se apenas algumas poucas dessas compreensões influenciam as discussões e as decisões, os atores políticos ficam mais propensos a perpetuar a injustiça ou a agir com imprudência ${ }^{37}$.

Will Kymlicka tece dois argumentos acerca da representação especial de grupos sociais que de outra forma tenderiam a ser marginalizados. Primeiramente, ele afirma que tal representação se justifica por combater a discriminação sistemática tanto no sistema político como na sociedade em geral. Esse argumento converge com aqueles que acabo de apresentar. $\mathrm{O}$ outro argumento, no entanto, vai num sentido um tanto diverso. Para Kymlicka, a representação

\section{Cf. De Greiff, 2000.}

37. Tanto esse argumento como o anterior podem constituir aspectos do argumento de Melissa Williams de que a representação de grupos promove "voz" política. Susan, por sua vez, desenvolve um argumento particularmente nuançado acerca da representação especial de grupos marginalizados em circunstâncias de desigualdade estrutural (Bickford, 1999: 86-108). Ao enfatizar a pluralidade dos contextos e formas de representação e ao conceber que os próprios processos de representação influenciam o modo como os grupos compreendem a si mesmos e se relacionam entre si, ela sugere que as teorias e as práticas da representação de grupos não necessariamente assumem uma identidade de grupo essencial. Segundo a autora, o propósito da representação específica de grupos estruturais não é expressar uma identidade, mas dar voz às experiências e perspectivas daqueles socialmente posicionados naquilo que denominei como "séries sociais" (cf. Young, 2000, cap. 3 [N.T.]). 
de grupos também se justifica com base no autogoverno. Alguns grupos, que ele chama de "nações" e cujo paradigma são os povos indígenas, teriam direito ao autogoverno. Nas sociedades multiculturais, os diversos grupos que fazem jus ao autogoverno devem fazer parte dos organismos políticos mais amplos mediante complexas relações federativas. Grupos que têm direito ao autogoverno, mas que também integram os organismos políticos mais amplos, devem ser representados como grupos nas instâncias de tomadas de decisão desses organismos, assim como nas comissões, conselhos e negociações intergovernamentais ${ }^{38}$.

A meu ver, Kymlicka está correto ao distinguir essas duas justificativas para a representação de grupos, e creio que o autogoverno num contexto de relações políticas mais amplas oferece uma justificativa adicional àquelas que expus acima. No entanto, os povos diferenciados que reivindicam o autogoverno também vivenciam relações de desigualdade 176 estrutural ou de potencial dominação com outros grupos ${ }^{39}$.

Deve-se ainda assinalar que nem os argumentos de Kymlicka nem aqueles que apresentei acima implicam uma justificativa da representação de grupos em termos de diversidade, reconhecimento ou afirmação da identidade grupal $^{40}$. O processo de mobilização dos membros de um grupo visando à sua inclusão e participação nas instituições representativas e nas discussões das questões da agenda da sociedade freqüentemente invoca, e com razão, auto-imagens de distinção e orgulho. No entanto, os grupos não fazem jus à representação especial em organismos de toma-

38. Kymlicka, 1996, cap. 7.

39. Para a posição da autora acerca da questão dos povos diferenciados, do autogoverno e da representação de grupos em organismos federativos, cf. Young, 2000, cap. 7 [N.T.].

40. Para David Miller (1995, cap. 5), esse é um argumento primordial para a representação de grupos. 
das de decisão inclusivos apenas por expressar suas culturas no debate público, ou ser reconhecidos em suas características distintivas ${ }^{41}$.

Esses argumentos acerca da representação de perspectivas sociais, que de outra forma permaneceriam silenciadas, também implicam que os interesses ou as opiniões de minorias ou grupos desfavorecidos devem ser especialmente representados? Para responder à questão, é preciso antes retomar as diferenças entre as perspectivas e os interesses e opiniões. As perspectivas sociais emergem de amplas estruturas sociais que posicionam similarmente muitas pessoas, quer elas gostem ou não. Isso confere às perspectivas sociais um caráter básico que muitos interesses e opiniões não possuem. Interesses e opiniões podem ser compartilhados com muitas outras pessoas ou podem ser bastante idiossincráticos. Muitos são voluntariamente formados e organizados, e é potencialmente vasta a quantidade de interesses e opiniões numa dada sociedade.

No entanto, a diferença mais relevante entre perspectivas e interesses/opiniões é que dentre esses últimos podem ser afirmados alguns que sejam perversos ou ilegítimos, ao passo que uma perspectiva social não é em si mesma ilegítima. Numa sociedade em que a população branca seja privilegiada, por exemplo, a perspectiva social das pessoas brancas, com freqüência, terá um predomínio incorreto nas diversas discussões públicas, e deverá então ser relativizada e matizada pelas perspectivas sociais das pessoas posicionadas diferentemente nas estruturas sociais racializadas. Mas a perspectiva da população branca não é em si incorreta ou ilegítima. Já as opiniões decorrentes do princípio da supremacia racial branca, que demandariam a segregação forçada de todas as pessoas de cor, essas sim são ilegítimas, pois

41. Cf. De Greiff, 2000. 
afirmam a recusa a reconhecer certos membros da sociedade igualmente como participantes dessa sociedade. Uma sociedade liberal em que tais opiniões fossem sustentadas por uma pequena minoria teria de permitir que esta expressasse opiniões, mas não seria obrigada a lhe dar nenhum apoio só pelo fato de tal minoria estar em desvantagem na repercussão de suas opiniões.

De modo geral, os princípios liberais de livre expressão e associação devem nortear a representação dos interesses e opiniões. Todos devem ter liberdade de expressar opiniões e de se organizar coletivamente para torná-las públicas. Todos devem ser livres para organizar grupos a fim de promover interesses particulares. Ambas as liberdades devem ser limitadas por regras que garantam uma similar liberdade aos outros e proíbam atividades que lhes provoquem danos injustamente. O conteúdo desse princípio de dano é notoriamente contestado, mas não vou aqui entrar nessa

178 controvérsia. A questão de fundo, enfim, é que maximizar a liberdade de expressão e associação deve ser o princípio geral da representação de interesses e opiniões.

Alguns críticos do liberalismo de grupos de interesse observam, porém, que a irrestrita liberdade de expressão e associação leva a flagrantes injustiças num sistema econômico em que alguns interesses e opiniões têm muito mais acesso a recursos que outros. Em resposta a essa preocupação, alguns dos argumentos destinados a justificar medidas especiais para assegurar a representação de perspectivas também podem fundamentar medidas especiais para assegurar a representação de interesses ou opiniões no debate público. A igualdade política pode requerer a garantia de acesso à mídia aos grupos de interesse com poucos recursos, ou a limitação da capacidade dos grupos mais abastados de dominar os canais de influência pública. Além disso, como sugerem Joshua Cohen e Joel Rogers, um sistema de representação de grupos de interesse justo deve subsidiar 
a auto-organização daqueles que têm interesses legítimos, mas contam com poucos recursos ${ }^{42}$.

$\mathrm{O}$ argumento de que todas as perspectivas dos grupos sociais diferenciados devem estar representadas nas tomadas de decisão políticas não especifica quem faz a representação. Duas questões são relevantes a esse respeito. É necessário que a pessoa que representa a perspectiva de um grupo social num determinado contexto político seja um membro daquele grupo? A proposta de representar a perspectiva em vez - digamos - do interesse dos grupos vai mais longe no encaminhamento do problema de haver um só representante para muitos representados? A seguir, examino brevemente essas duas questões.

Somente pessoas com certos atributos descritivos podem representar a perspectiva de um grupo social estrutural? Se a representação consiste num relacionamento entre uma base eleitoral e um representante no qual a base discute internamente sobre as questões a serem representadas e convoca o representante a prestar contas, então a base eleitoral constituída por um grupo social certamente pode e deve se perguntar quão bem uma pessoa dotada dos supostos atributos descritivos efetivamente representa sua perspectiva social. Ademais, é possível - ainda que eu não considere muito comum - que uma pessoa desprovida dos atributos descritivos represente uma perspectiva. Para tanto, porém, é preciso que ela esteja situada em relações sociais que lhe propiciem experiências e percepções sociais similares às daquela pessoa que possui os atributos descritivos. Um homem asiático-americano que tenha crescido em meio a uma vizinhança predominantemente afro-americana, que tenha muitos amigos afro-americanos e que agora trabalhe em um serviço comunitário localizado num bairro com muitos afro-americanos,

42. Cohen e Rogers, 1996. Cf. também Christiano, 1996:. 248-257. 
por exemplo, pode estar apto a representar uma perspectiva afro-americana em várias discussões, mas muitos outros asiático-americanos não estariam, pois na maioria das vezes estão posicionados de modo diferente.

A segunda questão pergunta se realmente superamos o problema da representação de muitos por um só ao passarmos da representação dos interesses de grupos para a representação da perspectiva de grupos. Argumentei anteriormente que a idéia de perspectiva é mais fluida e aberta que a idéia de interesse, uma vez que a perspectiva é uma orientação geral sobre as questões políticas que não determina o que se vê e não dita conclusões específicas. Não obstante, há boas razões para não supor que uma perspectiva social seria unificada a ponto de que todos os indivíduos estruturalmente posicionados de modo similar expressassem questões, condicionados da mesma maneira por essa perspectiva situada. Por isso, um esquema de representação de grupos

180 teria maior alcance ao pluralizar tal representação. A representação da perspectiva das mulheres numa comissão ou num órgão legislativo, por exemplo, seria mais efetiva por meio de um pequeno comitê de mulheres do que por uma só mulher. Um comitê pode conter algumas das diferenças de perspectiva que perpassam o grupo, bem como diferenças de experiências, capacidades e critérios individuais, o que pode habilitá-lo a analisar situações sociais a partir da perspectiva de gênero e expressar essa perspectiva para um público mais amplo ${ }^{43}$.

\section{Aplicação do argumento}

Argumentei que o compromisso com a igualdade política implica que as instituições e práticas democráticas tomem medidas explícitas para incluir a representação de grupos

43. Cf. Weldon, 1999. 
sociais cujas perspectivas provavelmente seriam excluídas das discussões, na ausência daquelas medidas. Esses grupos constituem uma minoria relativamente pequena ou são social ou economicamente desfavorecidos, ou então o discurso político prevalecente é dominado por outras perspectivas. Os grupos sociais devem ser reconhecidos e incluídos em sua especificidade nos processos comunicativos democráticos.

A questão que agora se coloca é como tal representação específica deve ser efetivada. Melissa Williams aponta que muitas das objeções ao princípio geral da representação de grupos, na verdade, se opõem a determinadas formas de implementação da representação de grupos, tais como a que lhes reserva um certo número de cadeiras parlamentares ${ }^{44}$. Há várias formas de aplicar o princípio de que os processos de discussão e tomada de decisões devem tomar medidas de inclusão de grupos sociais cujas perspectivas de outra forma tenderiam a ser excluídas. Definir quais seriam as melhores medidas depende da situação política, da natureza das clivagens estruturais da sociedade, de possíveis arranjos e permutas (trade-offs) com outros valores políticos e do contexto institucional da representação. Embora muitas críticas à representação de grupos pareçam ter em mente apenas os órgãos legislativos nacionais, a representação de perspectivas sociais também pode ocorrer em legislaturas locais, em comissões e comitês dos poderes públicos, em instâncias dos partidos políticos e na esfera mais ampla das associações corporativas e civis. A meta de introduzir mais membros de grupos marginalizados em tais organismos pode ser alcançada por vários meios, tais como nomeação para cargos, esquemas de votação, sorteios, formação de eleitorados por segmentos socioeconômicos e profissionais etc.

44. Williams, 1998, cap. 7. 
Levando em conta que não há uma fórmula geral para aplicar um princípio de representação inclusiva, examinarei brevemente algumas questões relacionadas às opções de implementação mais discutidas. Esse exame se concentrará em propostas de ampliação da representação de grupos nos parlamentos, embora eu creia que muitos outros contextos são pelo menos tão importantes quanto os parlamentos para implementar a representação inclusiva. É no contexto das legislaturas que as questões da representação de grupos são mais contestadas, tanto na vida pública quanto no debate acadêmico.

Um dos métodos da representação de grupos consiste em reservar num órgão representativo um certo número de cadeiras para representantes de determinados grupos. Alguns autores manifestam certas dúvidas pertinentes sobre os efeitos desse método. Reservar cadeiras para grupos específicos pode tender a congelar tanto as identidades des182 ses grupos quanto as suas relações com os outros grupos da sociedade, de modo que seria desejável um procedimento mais fluido, que se adaptasse à dinâmica das relações sociais. Ao mesmo tempo, reservar cadeiras pode tender a congelar os membros de um grupo especialmente representado em relação a outras oportunidades de representação, de modo que esse grupo pode ficar isolado e marginalizado no âmbito representativo. Sabendo que têm cadeiras reservadas, os grupos podem tornar-se pouco ativos nos processos de autorização e prestação de contas, os representantes podem tender a se desconectar das bases eleitorais dos grupos e as cadeiras podem ficar vulneráveis à cooptação por partidos ou interesses. Além disso, se apenas os membros do grupo têm o direito de escolher quem ocupará as cadeiras reservadas, gera-se o difícil problema de determinar quem tem o direito de escolher aqueles representantes. Pode-se argumentar que todos esses problemas obstruíram o sistema de representação que reservou cadeiras aos maoris, no 
Parlamento da Nova Zelândia, antes que a mudança para um sistema de representação proporcional facilitasse a um partido maori eleger maoris nas eleições legislativas gerais.

Esses problemas parecem levar à conclusão de que reservar cadeiras em organismos deliberativos eleitos deve ser uma opção temporária e de última instância para a representação de perspectivas que, de outra forma, permaneceriam excluídas. Já em organismos não-eletivos, tais como comissões, o método parece ser menos problemático, uma vez que esses organismos normalmente são temporários e têm uma incumbência limitada. Evidentemente, esses organismos só são representativos num sentido político se há uma base eleitoral organizada para a qual a comissão tenha de prestar contas.

Cotas para mulheres em listas de candidatos e regras sobre uma certa proporção de membros de grupos raciais ou étnicos minoritários em convenções partidárias freqüentemente são modos aceitáveis e desejáveis de promover a inclusão de perspectivas e interesses diversificados. Esse método não discrimina membros de grupos e os inclui nas deliberações partidárias. Dependendo da quantidade de partidos e dos sistemas de votação, os eleitores de todos os grupos continuam a ter diversas opções de candidatos.

David Ryden afirma que fortalecer a formação e a deliberação participativa de partidos políticos é a melhor forma de fomentar a representação de grupos sociais politicamente motivados, argumentando que medidas especiais de representação de grupos nas instituições representativas públicas tenderiam a congelar as identidades dos grupos e a fragmentar a política ${ }^{45}$. Concordo com a idéia de que os partidos políticos podem ser um importante instrumento para a aplicação dos princípios de representação inclusiva

45. Ryden, 1996: 110-138. 
de perspectivas sociais. Sem medidas afirmativas que propiciem a representação de grupos em suas instâncias deliberativas, listas de candidatos, convenções etc., os partidos políticos - especialmente os partidos grandes ou já consolidados, que detenham algum poder político - tendem a padecer do mesmo viés das instituições do Estado no sentido de representar os interesses e as perspectivas dos segmentos sociais privilegiados. Para promover a inclusão de todas as perspectivas sociais nas discussões e tomadas de decisão políticas, os partidos precisam então dedicar especial atenção aos grupos e a medidas compensatórias à sua sub-representação.

Nos Estados Unidos, nos anos recentes, a demanda da criação de distritos eleitorais com maiorias afro-americanas ou latino-americanas tem sido uma das formas de tentar promover a representação de grupos cujas perspectivas estariam de outra forma ausentes do debate público. A legitimidade da delimitação de distritos especificamente para asse184 gurar a representação de grupo é intensamente contestada, mas não reproduzirei aqui os termos dessa discussão. A veemência do debate leva-me a concluir que a delimitação de distritos geográficos para fins de representação de grupos não é a opção preferida, mas penso que esse método não é em si incorreto ou injusto. Num sistema político, que se baseia em distritos eleitorais do tipo "membro único", em que "o vencedor leva tudo", configurar os distritos de modo que grupos minoritários - estrutural ou culturalmente diferenciados e socialmente desfavorecidos - estejam em maioria pode ser a única forma de fazer que os membros desses grupos apareçam como representantes, propiciando que as perspectivas sociais desses grupos tenham mais voz na discussão pública. Uma vez que a igualdade envolve inclusão nesse sentido, tais soluções distritais não são incorretas ${ }^{46}$.

46. Cf. Gutmann, 1996. 
Não obstante, concordo com a crítica de Lani Guinier aos distritos "minoritário-majoritários" como solução preferencial para a representação de grupos sociais ${ }^{47}$. A distritalização pressupõe que os grupos marginalizados são suficientemente segregados no espaço para que se configurem territórios relativamente homogêneos. Mesmo nos Estados Unidos, onde essa solução é predominante na questão da representação dos grupos racializados, é praticamente impossível construir distritos homogêneos. Quando se delimita um distrito explicitamente para promover a representação de uma determinada perspectiva de grupo, a minoria que é menos afiliada ao grupo naquele distrito pode, com razão, sentir-se sub-representada. É menos provável que sejam suscitados tais sentimentos num sistema de votação que dê a todos mais opções sobre o que podem afirmar com seus votos e sobre com quem se alinhar ao votar.

Guinier argumenta, a meu ver irrefutavelmente, que jurisdições eleitorais plurinominais (multi-member) com alguma forma de votação cumulativa e representação proporcional maximizariam tais opções, estimulariam coalizões no interior do grupo e, ao mesmo tempo, propiciariam oportunidades organizacionais para que grupos marginalizados ou desfavorecidos fossem representados. Além disso, os efeitos dos distritos "majoritário-minoritários" podem ser similares aos das cadeiras reservadas, nas quais eles se tornam "incólumes". Os representantes distritais tendem então a se afastar dos eleitores e estes a se tornar relativamente passivos em relação aos seus representantes. Num sistema com distritos multimembros e representação proporcional, os cidadãos precisam ser ativos para promover a representação dos interesses e perspectivas que mais lhes são caros. Unidades políticas plurinominais com repre-

47. Guinier, 1995. 
sentação proporcional obviamente propiciam uma solução melhor para a representação das perspectivas de grupos espacialmente dispersos.

Diversos trabalhos recentes sobre igualdade política apresentam argumentos similares e sólidos acerca de esquemas de votação que usam um ou outro método de representação proporcional baseado em distritos plurinominais. A representação proporcional tende a aumentar a competição partidária e a habilitar mais partidos a obter cadeiras legislativas do que os sistemas em que "o vencedor leva tudo". Alguns autores argumentam que o sistema de representação proporcional também propicia aos eleitores maiores oportunidades de se juntar a outros em "comunidades de interesses", tais como um grupo social estrutural. Creio que esses argumentos são persuasivos ao fundamentar a visão de que a representação proporcional provê maior oportunidade para a representação diferenciada do que um sistema baseado em 186 distritos com membro único, em que o vencedor leva tudo ${ }^{48}$.

No entanto, as legislaturas não são os únicos organismos públicos aos quais os argumentos sobre a representação de grupos podem ser aplicados. Instâncias judiciárias, audiências públicas, comitês e comissões e processos consultivos estão entre os outros organismos de discussão e tomada de decisões em que a representação inclusiva pode ser exercida, mesmo quando suas composições não sejam determinadas pelo voto dos cidadãos. Nas décadas recentes, tem-se dedicado cada vez mais atenção à representação de diversos grupos em organismos como esses. Um governo representativo democrático deve ter várias instâncias de organismos eleitos, nomeados e voluntários que discutam opções de políticas, tomem decisões sobre políticas ou supervisionem a efetividade das políticas adotadas. Em tais organismos, é

48. Cf. Guinier, 1995; Christiano, 1996: 224-242; Beitz, 1990, cap. 6. 
possível e desejável que haja representação de perspectivas sociais de grupos que, de outra forma, não poderiam se fazer presentes. Se se tivesse dado maior atenção à representação especial de grupos oprimidos ou desfavorecidos no processo de organização dos grupos de discussão civis que fundamentaram a elaboração do plano de racionamento dos serviços de saúde no estado de Oregon em 1990, por exemplo, aqueles grupos de discussão provavelmente não teriam sido dominados pelas perspectivas da classe média branca e com maior escolaridade ${ }^{49}$.

O processo de autorização e responsabilização que constitui a prática representativa não deve enfim ser confinado aos organismos públicos oficiais. Já assinalei aqui que a livre associação da sociedade civil contribui para a formação e a expressão de interesses e opiniões. A sociedade civil também é uma importante instância de consolidação e expressão de perspectivas sociais. Ademais, a organização e a mobilização nas esferas públicas da sociedade civil estão entre os meios mais efetivos de se manter as conexões entre representantes e eleitores, e de se efetivar a prestação de contas dos representantes. Aprofundamos a democracia quando encorajamos o florescimento das associações que as pessoas formam de acordo com os interesses, opiniões e perspectivas que consideram importantes. As atividades autônomas e plurais das associações civis propiciam aos indivíduos e aos grupos sociais, em sua própria diversidade, uma inestimável oportunidade de serem representados na vida pública ${ }^{50}$.

\section{Iris Marion Young}

é professora de Ciência Política da Universidade de Chicago

49. Ver Garland, 1990: 183-200.

50. No original, a autora assim conclui o texto: "Dessa forma, a seguir [Capítulo 5 de Inclusion and democracy, 2000] delineia-se uma teoria de como a sociedade civil contribui para uma democracia comunicativa inclusiva" [N.T.]. 


\section{Bibliografia}

ALCOFF, Linda. 1991. "The problem of speaking for others". Cultural Critique, n. ${ }^{\circ}$ 20, p. 5-32.

BARBER, Benjamin. 1984. Strong democracy. Berkeley: University of California Press.

BEITZ, Charles. 1990. Political equality. Princeton: Princeton University Press. BICKFORD, Susan. 1999. "Reconfiguring pluralism: identity and institutions in the inequalitarian polity”. American Journal of Polical Science, vol. 43, n. ${ }^{\circ} 1$, p. $86-108$.

CHRISTIANO, Thomas. 1996. The rule of the many. Boulder, CO: Westview Press.

COHEN, Cathy J. 1997. "Straight gay politics: the limits of an ethnic model of inclusion”. In: SHAPIRO, Ian e KYMLICKA, Will (orgs.). Ethnicity and group rights. Nova York: New York University Press.

COHEN, Joshua e ROGERS, Joel. 1996. "Secondary associations and democratic governance". In: WRIGHT, Eric 0. (org.). Associations and democracy. Londres: Verso.

DAHL, Robert. 1989. Democracy and its critics. New Haven, CT: Yale University Press.

DE GREIFF, Pablo. 2000. "Deliberative democracy and group representation”. In: GRACIA, Jorge e DE GREIFF, Pablo (orgs.). Hispanics/Latinos in the US. Nova York: Routledge.

DERRIDA, Jacques. 1973a. On grammatology. Baltimore: Johns Hopkins University Press.

1973b. "Différance". In: Speech and phenomena and other essays:

Husserl's theory of signs. Evanston, IL: Northwestern University Press. . 1982. "Sending: on representation". Social Research, n. ${ }^{\circ} 49$, p. 294-326.

DHANDA, Meena. 1998-1999. "Justifications for gender quotas in legislative bodies: a consideration of identity and representation”. Women's Philosophy Review 20: 44-62.

DRYZEK, John. 1990. Discursive democracy. Cambridge: Cambridge University Press.

FISHKIN, James. 1995. The voice of the people. New Haven: Yale University Press.

GARLAND, Michael J. e HASRAEN, Romana. 1990. "Community reponsability and the development of Oregon's health care priorities". Business and Professional Ethics Journal, vol. 9. n. ${ }^{\circ}$ 3/4, p. 183-200.

GREEN, Philip. 1985. Retrieving democracy. Totowa, NJ: Rowman \& Allenheld. 
GUINIER, Lani. 1995. "Groups, representation, and race conscious districting”. In: The tyranny of the majority. Nova York: The Free Press.

GUTMANN, Amy. 1996. "Responding to racial injustice". In: APIAH, K. Anthony e GUTMANN, Amy. Color conscious. Princeton: Princeton University Press.

e THOMPSON, Dennis. 1996. Democracy and disagreement.

Cambridge, MA: Harvard University Press.

HIRST, Paul. 1990. Representative democracy and its limits. Oxford: Polity Press.

HOCHSCHILD, Jennifer. 1995. Facing up to the American dream: race, class, and the soul of the Nation. Princeton: Princeton University Press.

KINDER, Donald. 1996. Divided by color: racial politics and democratic ideals. Chicago: University of Chicago Press.

KYMLICKA, Will. 1996. Multicultural citizenship. Nova York: Oxford University Press.

MANSBRIDGE, Jane. 1997. "Should blacks represent blacks and woman represent woman? A contingent 'yes'”. The Journal of Politics, vol. 61, n. ${ }^{\circ}$ 3, p. $628-657$.

MILLER, David. 1995. On nationality. Oxford: Oxford University Press.

MINOW, Martha. 1990. Making all the difference. Ithaca, NY: Cornell University Press.

MONROE, Kristin R. e KREIDI, Lina H. 1997. "The perspective of Islamic fundamentalists and the limits of rational choice theory". Political Psychology, vol. 18, n. ${ }^{\circ}$ 1, p. 19-43.

MOUFFE, Chantal. 1993. "Feminism, citizenship and politics". In: The return of the political. Londres: Verso.

PHILLIPS, Anne. 1993. "Democracy and difference". In: Democracy and difference. University Park, PA: Pennsylvania State University Press. . 1995. The politics of presence. Oxford: Oxford University Press.

PITKIN, Hanna. The concept of representation. Berkeley: University of California Press, 1971.

PLOTKE, David. 1997. "Representation is democracy". Constellations, vol. 4, n. ${ }^{\circ} 1$.

RAWLS, John. 1993. Political liberalism. Nova York: Columbia University Press.

RYDEN, David. 1996. Representation in crisis: the Constitution, interests groups, and political parties. Albany, NY: State University of New York Press.

SANDERS, Lynn. 1997. "Against 'deliberation'”. Political Theory, vol. 25, n. ${ }^{\circ}$ 3, p. 347-376.

SCHWARTZ, Nancy. 1988. The blue guitar: political representation and community. Chicago: University of Chicago Press. 
SHAPIRO, Ian e KYLICKA, Will. 1997. Ethnicity and group rights (Nomos 39). Nova York: New York University Press.

WELDON, S. Laurel. 1999. "The political representation of women: the impact of a critical mass". In: DAVIS, Rebecca. Stand! Contending ideas and issues: comparative politics. Boston, MA: Houghton Mifflin.

WILLIAMS, Melissa. 1998. Trust and memory: marginalized groups and the failure of liberal representation. Princeton: Princeton University Press.

YOUNG, Iris M. 1997. "Deferring group representation". In: SHAPIRO e KYMLICKA (orgs.), Ethinicity and group rights (Nomos 39), cit.

YOUNG, Iris M. 1995. "Rawls's Political liberalism". Journal of Political Philosophy, vol. 3, n. ${ }^{\circ}$ 1, p. 181-190.

YOUNG, IRIS M. Justice and the politics of difference. Princeton: Princeton University Press, 1990. 


\section{( )}

\section{REPRESENTAÇÃO POLÍTICA, IDENTIDADE E MINORIAS}

IRIS MARION YOUNG

O texto examina os dilemas de inclusão enfrentados pela democracia e desenvolve um modelo analítico para se pensar na representação de minorias em termos compatíveis com exigências universalistas inerentes à cidadania e à democracia modernas.

Palavras-chaves: Democracia e inclusão; Diferença e representação; Minorias.

\section{POLITICAL REPRESENTATION, IDENTITY AND MINORITIES}

The article examines the dilemmas of inclusion faced by democracy. It unfolds a analytic model to think on the representation of minorities in terms compatible to the universalistic demands of modern citizenship.

Keywords: Democracy and inclusion; Difference and representation; Minorities. 